\title{
SCIENTIFIC REPORTS

\section{Effects of engineered aluminum and nickel oxide nanoparticles on the growth and antioxidant defense systems of Nigella arvensis L.}

\author{
Azam Chahardoli ${ }^{1,2^{*}}$, Naser Karimi ${ }^{1}$, Xingmao $\mathrm{Ma}^{3}$ \& Farshad Qalekhani ${ }^{2}$
}

The effects of different concentrations $(0,50,100,1000$ and $2500 \mathrm{mg} / \mathrm{L})$ of engineered aluminum and nickel oxide nanoparticles $\left(\mathrm{Al}_{2} \mathrm{O}_{3}\right.$ and NiO NPs) on plant growth, oxidative stress and antioxidant activities in the hydroponically grown tissues of Nigella arvensis $\mathrm{L}$. were investigated. The plant biomass was significantly increased under 50 and $100 \mathrm{mg} / \mathrm{L}$ of $\mathrm{Al}_{2} \mathrm{O}_{3} \mathrm{NPs}$ or $50 \mathrm{mg} / \mathrm{L}$ of NiO NPs treatment, but was significantly decreased at higher concentrations of these nanoparticles. Assays of several enzymatic antioxidants such as ascorbate peroxidase (APX), catalase (CAT), superoxide dismutase (SOD) and peroxidase (POD) in roots and shoots indicate a general increase of activities after exposure to $50-2,500 \mathrm{mg} / \mathrm{L}$ of $\mathrm{Al}_{2} \mathrm{O}_{3} \mathrm{NPs}$ and NiO NPs. The results are corroborated by an increased 2,2-diphenyl1-picryl hydrazyl (DPPH) scavenging activity, total antioxidant capacity, total reducing power, total iridoids content, total saponin content, and total phenolic content in treated plants by $\mathrm{Al}_{2} \mathrm{O}_{3} \mathrm{NPs}$ compared to the control plants. By contrast, the antioxidant activities, formation of secondary metabolites, and other related physiological parameters such as the total antioxidant capacity, DPPH scavenging activity and total saponin content were inhibited after the concentration of NiO NPs was increased to $100 \mathrm{mg} / \mathrm{L}$. Total phenols, saponins, iridoids and total antioxidant content and DPPH scavenging activity were increased in plants treated with $100-2,500 \mathrm{mg} / \mathrm{L} \mathrm{Al}_{2} \mathrm{O}_{3} \mathrm{NPs}$. Overall, these two nanoparticles displayed different effects in the shoots and roots of plants at different concentrations, which may be due to their physico-chemical properties.

Rapid development of nanotechnology has greatly expanded the applications of engineered nanoparticles (ENPs) in commercial and industrial products ${ }^{1}$. Increased application and potential accumulation of ENPs in the environment and their unknown interactions with different organisms, aggravated by some reports of greater toxicity at nanoscale than the bulk scale, caused broad concerns about the environmental health and safety of ENPs ${ }^{2,3}$. Previous studies have demonstrated some disruptive effects of some ENPs on the natural environment including water, air, and soil quality ${ }^{4}$. Plants are one of the most essential components of the ecosystem and interact with ENPs closely ${ }^{5}$. These ENPs could be taken up by plants, and enter into the food chain through dietary consumption, ultimately affecting human health ${ }^{6}$.

Many previous investigations explored the potential applications of ENPs in agriculture $\mathrm{e}^{7-10}$. However, the majority of previous studies in ENPs - plant interactions focused on the potential toxicity of nanoparticles to higher plants. Both positive and negative or insignificant effects of ENPs on plants have been reported ${ }^{11}$. In general, the phytotoxicity of ENPs is mediated through the production of reactive oxygen species (ROS) in plant cells ${ }^{12}$. Even though ROS are normally produced within plants as a byproduct of metabolic processes in chloroplasts and other organelles ${ }^{13,14}$, excessive production of ROS can disrupt plant photosynthesis and other physiological and biochemical processes, eventually triggering the defense mechanisms in plants such as greater activities of certain antioxidants ${ }^{15}$. In addition, accumulation of ENPs can stimulate defense mechanisms through antioxidant enzymes to scavenge the deleterious $\operatorname{ROS}^{16}$.

\footnotetext{
${ }^{1}$ Department of Biology, Faculty of Science, Razi University, Kermanshah, Iran. ${ }^{2}$ Medical Biology Research Center, Kermanshah University of Medical Sciences, Kermanshah, Iran. ${ }^{3}$ Zachry Department of Civil and Environmental Engineering, Texas A\&M University, TAMU 3136, College Station, TX, 77843-3136, USA. *email: a.chahardoly@ gmail.com
} 


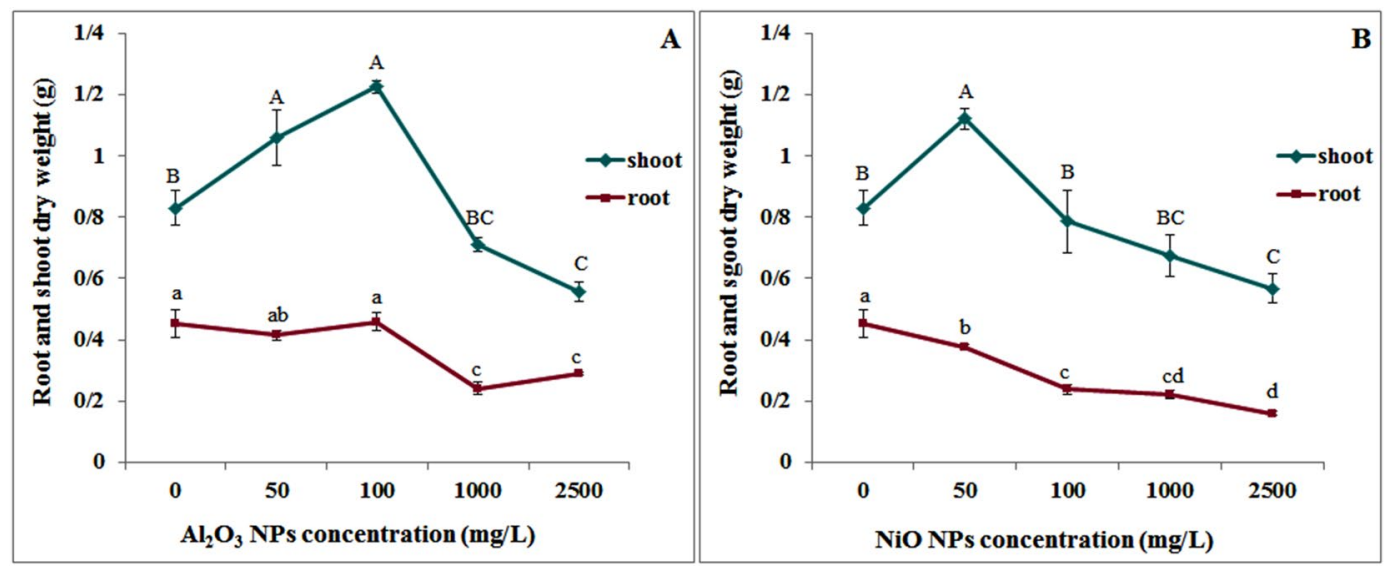

Figure 1. Effects of (A) $\mathrm{Al}_{2} \mathrm{O}_{3} \mathrm{NPs}$ and (B) NiO NPs treatment on plant biomass of N. arvensis.

The amount of ROS and antioxidant responses vary with metal oxide nanoparticle types, exposure conditions and plant species ${ }^{15}$. For example, $\mathrm{La}_{2} \mathrm{O}_{3} \mathrm{NPs}$ at $2,000 \mathrm{mg} / \mathrm{L}$ of induced significant ROS production and cell death in cucumber (Cucumis sativus L.) ${ }^{17}$. However, no significant effects was observed when cucumber was exposed to $0.2-200 \mathrm{mg} / \mathrm{L} \mathrm{CeO} \mathrm{NPs}^{17}$. Cerium oxide nanoparticles $\left(\mathrm{CeO}_{2} \mathrm{NPs}\right)$ increased $\mathrm{H}_{2} \mathrm{O}_{2}$ content in Zea mays and Brassica rapa ${ }^{18,19}$ but decreased the $\mathrm{H}_{2} \mathrm{O}_{2}$ content in Oryza sativa ${ }^{20,21}$. Hu et al. ${ }^{22}$ showed that $\mathrm{SOD}$ and CAT activities significantly increased in Salvinia natans treated with $50 \mathrm{mg} / \mathrm{L} \mathrm{ZnO} \mathrm{NPs}{ }^{22}$. Kim et al. ${ }^{23}$ also reported high activities of SOD, POD and CAT following $\mathrm{ZnO}$ and $\mathrm{CuO}$ NPs $(100 \mathrm{mg} / \mathrm{L})$ applications to cucumber plants ${ }^{23}$.

Among the most abundant nanoparticles produced in the industrial and commercial sectors are aluminum oxide nanoparticles $\left(\mathrm{Al}_{2} \mathrm{O}_{3} \mathrm{NPs}\right.$ ) and nickel oxide nanoparticles ( $\mathrm{NiO} \mathrm{NPs}$ ). $\mathrm{Al}_{2} \mathrm{O}_{3} \mathrm{NPs}$ are widely used in various military and commercial products ${ }^{24,25}$. For example, they have been used in catalyst support and microelectron$\mathrm{ics}^{26}$ and in semiconductor materials, glass products, rocket fuel, explosives, wear-resistant coatings for ships, packaging materials, cosmetic fillers, plastics and sensors ${ }^{27-29}$. The phytotoxicity of $\mathrm{Al}_{2} \mathrm{O}_{3} \mathrm{NPs}$ was reported in tobacco and wheat ${ }^{30,31}$. Lee et al. ${ }^{32}$ investigated the phytotoxicity of $\mathrm{Al}_{2} \mathrm{O}_{3} \mathrm{NPs}(\sim 150 \mathrm{~nm})$ to Arabidopsis thaliana at concentrations of $400,2,000$ or $4,000 \mathrm{mg} / \mathrm{L}$ and no toxic effects were observed ${ }^{32}$. Some positive effects of $\mathrm{Al}_{2} \mathrm{O}_{3}$ NPs were reported on the root growth of ryegrass, radish, lettuce and rape plants ${ }^{33}$. Riahi-Madvar et al. ${ }^{31}$ showed that antioxidant enzyme activities of wheat plant decreased the damaging effects of $\mathrm{Al}_{2} \mathrm{O}_{3} \mathrm{NPs}$ by scavenging the induced $\operatorname{ROS}^{31}$.

Nickel oxide nanoparticles (NiO NPs) have many novel properties compared to their bulk counterpart and are widely used in catalytic materials, sensors, magnetic materials, battery electrode, diesel-fuel additives and electrochromic films $\mathrm{s}^{34,35}$. It has been reported that NiO NPs can be easily transported into plants inducing cytotoxic and genotoxic effects ${ }^{36}$. Feisal et al. ${ }^{37}$ reported that NiO NPs at $0.025-2.0 \mathrm{mg} / \mathrm{mL}$ led to oxidative stress, mitochondrial dysfunction, lipid peroxidation and apoptosis/necrosis in tomato seedling roots ${ }^{37}$. The activity of antioxidative enzymes, including CAT, and SOD was improved. Dewez et al.38 indicated that both NiO NPs and bulk $\mathrm{NiO}$ at $1000 \mathrm{mg} / \mathrm{L}$ increased ROS generation and had high inhibitory effect on the PSII quantum yield, reducing the photosynthetic electron transport performance in Lemna gibba L. ${ }^{38}$.

The aims of this work were to investigate the impact of $\mathrm{Al}_{2} \mathrm{O}_{3}$ and $\mathrm{NiO} \mathrm{NPs}$ on the growth and antioxidative responses of Nigella arvensis at different concentrations. N. arvensis is a grassy plant with small black seeds known as the "seed of blessing". The plant belongs to the genus of Nigella and family of Ranculaceae. The seeds have been used to enhance flavor in cakes and bread. They are used as curative material for treating various diseases in some parts of the world. The seeds also demonstrate some therapeutic (for worm infestation), antiallergic, antiviral and anti-inflammatory properties ${ }^{39,40}$. In this study, we investigated the roles of $\mathrm{Al}_{2} \mathrm{O}_{3}$ and $\mathrm{NiO} \mathrm{NPs}$ on plant growth, intracellular ROS generation and levels of antioxidant responses for example activity of different antioxidant enzymes including CAT, APX, SOD and POD, as well as the alteration of secondary metabolites such as total phenolic, total iridoid and total saponin content, total antioxidant capacity, total reducing power and scavenging activity against DPPH free radical in the treated medicinal plant of $N$. arvensis.

\section{Results and Discussion}

Biomass assay. The results (Fig. 1A) showed that $\mathrm{Al}_{2} \mathrm{O}_{3} \mathrm{NPs}$ up to $100 \mathrm{mg} / \mathrm{L}$ stimulated the growth of $\mathrm{N}$. arvensis, but exerted toxicity at higher concentrations. The highest shoot and root dry weight $(1.2 \pm 0.02$ and $0.46 \pm 0.03 \mathrm{~g})$ and the lowest shoot and root weight $(0.55 \pm 0.03$ and $0.28 \pm 0.002 \mathrm{~g})$ was observed at 100 and $2500 \mathrm{mg} / \mathrm{L} \mathrm{Al} \mathrm{O}_{3} \mathrm{NPs}$ respectively. NiO NPs demonstrated significantly stronger effects than $\mathrm{Al}_{2} \mathrm{O}_{3} \mathrm{NPs}$ on the growth of $N$. arvensis. Maximum shoot and root dry weights (1.12 \pm 0.03 and $0.37 \pm 0.009 \mathrm{~g}$ respectively) were obtained at $50 \mathrm{mg} / \mathrm{L}$, and the lowest shoot and root dry weight $(0.56 \pm 0.04$ and $0.15 \pm 0.007 \mathrm{~g})$ were found at $2500 \mathrm{mg} / \mathrm{L} \mathrm{NiO}$ NPs (Fig. 1B). Consistent with our results, Asztemborska et al. ${ }^{41}$ also reported an increase in plant biomass of Allium cepa L., Zea mays, Lepidium sativum and Kalanchoe daigremontiana upon exposure to low concentrations of $\mathrm{Al}_{2} \mathrm{O}_{3} \mathrm{NPs}$, but a $33 \%$ decrease of root dry mass was noticed at the highest $\mathrm{Al}_{2} \mathrm{O}_{3}$ NPs concentration $(1000 \mathrm{mg} / \mathrm{kg})^{41}$. 


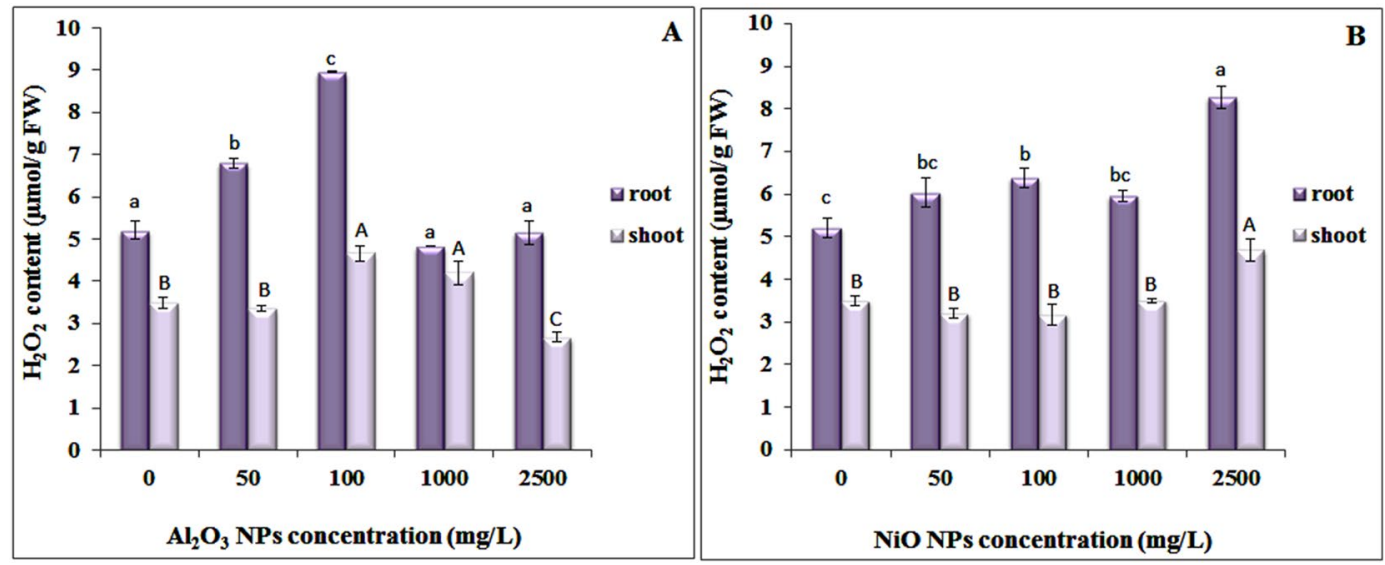

Figure 2. Effects of (A) $\mathrm{Al}_{2} \mathrm{O}_{3} \mathrm{NPs}$ and (B) NiO NPs treatment on $\mathrm{H}_{2} \mathrm{O}_{2}$ content in the roots and shoots of N. arvensis.

$\mathrm{H}_{2} \mathrm{O}_{2}$ content and antioxidant enzymes activity. ROS is normally formed as a by-product of plant cellular metabolism. Various environmental stresses can lead to overproduction of ROS in plants, which can cause progressive oxidative damage. After exposure to $\mathrm{Al}_{2} \mathrm{O}_{3} \mathrm{NPs}, \mathrm{H}_{2} \mathrm{O}_{2}$ content (a product of the superoxide dismutase reaction) in the roots of $N$. arvensis increased at 50 and $100 \mathrm{mg} / \mathrm{L}$ but decreased significantly at 1000 and $2500 \mathrm{mg} / \mathrm{L}$ to a comparable level of the control plants, suggesting that excessive amounts of ROS were scavenged by antioxidant enzymes at higher concentrations. However, $\mathrm{H}_{2} \mathrm{O}_{2}$ content in the shoot increased with the increase of $\mathrm{Al}_{2} \mathrm{O}_{3} \mathrm{NPs}$ up to $1000 \mathrm{mg} / \mathrm{L}$, indicating higher $\mathrm{Al}$ stress at higher concentrations (Fig. 2A). Formation of ROS can be a result of interactions between $\mathrm{Al}$ and plant cells ${ }^{42,43}$. Pakrashi et al. ${ }^{44}$ indicated that leached out $\mathrm{Al}^{3+}$ and electrostatic interactions between $\mathrm{Al}_{2} \mathrm{O}_{3} \mathrm{NPs}$ and algae cells might synergistically alter surface functional moieties on algal cells, resulting in oxidative stress and cell membrane damage ${ }^{44}$.

In $N$. arvensis treated with $\mathrm{NiO} \mathrm{NPs}, \mathrm{H}_{2} \mathrm{O}_{2}$ content in both root and shoot tissues increased significantly at $2500 \mathrm{mg} / \mathrm{L}$ compared to the control and other treatments. Exposure to $2500 \mathrm{mg} / \mathrm{L} \mathrm{NiO} \mathrm{NPs}$ increased the root $\mathrm{H}_{2} \mathrm{O}_{2}$ content by $59 \%$ compared to control, which functions as a signaling molecule in the induction and regulation of antioxidants. The $\mathrm{H}_{2} \mathrm{O}_{2}$ content in the shoots exposed to NiO NPs increased significantly by $34 \%$ at $2500 \mathrm{mg} / \mathrm{L}$ compared to the control, but was unaffected in other treatments (Fig. 2B). Other studies with Vicia narbonensis $\mathrm{L} .{ }^{45}$ and $\mathrm{Zea}$ mays ${ }^{19}$ treated with titanium oxide $\left(\mathrm{TiO}_{2}\right)$ and cerium oxide $\left(\mathrm{CeO}_{2}\right) \mathrm{NPs}_{\text {demonstrated }}$ little effects of these NPs on $\mathrm{H}_{2} \mathrm{O}_{2}$ accumulation in plant tissues, indicating that the induction of $\mathrm{H}_{2} \mathrm{O}_{2}$ in plants vary with the properties (e.g. composition) of metallic nanoparticles.

The activities of antioxidant enzymes in plants increase under environmental stresses ${ }^{46}$. Enhanced activities of antioxidant enzymes can increase plant tolerance to oxidative stress ${ }^{47}$. Figure 3 shows the activities of antioxidant enzymes in the roots and shoots of $N$. arvensis in the presence of $0-2500 \mathrm{mg} / \mathrm{L} \mathrm{Al}_{2} \mathrm{O}_{3}$ and NiO NPs. The CAT activity in the shoots and roots of $N$. arvensis increased with increasing ENPs levels for both nanoparticles ( $p<$ 0.01) (Fig. 3A), but the patterns of increase differed between these two ENPs. The CAT activity in plant tissues significantly increased after exposure to different concentrations of $\mathrm{Al}_{2} \mathrm{O}_{3} \mathrm{NPs}$ compared to the control plants, however, the differences between treatments with different concentrations of $\mathrm{Al}_{2} \mathrm{O}_{3} \mathrm{NPs}$ are generally insignificant. By contrast, the CAT activity displayed a dose-response relationship with NiO NPs, with higher NiO NPs leading to greater CAT activity in both roots and shoots (Fig. 3A). The exposure to CAT is one of the most important enzymes that scavenge ROS in plant cells. CAT partakes in the main defense system against the increase of $\mathrm{H}_{2} \mathrm{O}_{2}$ and can regulate the $\mathrm{H}_{2} \mathrm{O}_{2}$ levels in cells by converting it to water and oxygen ${ }^{48}$. The increased activity with increasing ENPs concentrations correlated with the decreased $\mathrm{H}_{2} \mathrm{O}_{2}$ content and lipid peroxidation in plants (Fig. 2), underscoring the importance of CAT in alleviating ENPs-induced oxidative stress. Furthermore, higher activity of CAT can be attributed to higher activities of SOD and higher production of $\mathrm{H}_{2} \mathrm{O}_{2}$. In agreement with our observations in roots and shoots, Laware and Raskar, (2014) found that the CAT activity in plants was increased upon exposure to $300 \mathrm{mg} / \mathrm{L} \mathrm{TiO}_{2} \mathrm{NPs}^{49}$. Also consistent with our previous results, CAT activity in tomato roots was not affected by up to $250 \mathrm{mg} / \mathrm{L} \mathrm{NiO} \mathrm{NPs} \mathrm{treatment,} \mathrm{but} \mathrm{its} \mathrm{activity} \mathrm{increased} \mathrm{significantly} \mathrm{in}$ treatments with 250 to $2000 \mathrm{mg} / \mathrm{L}$ of $\mathrm{NiO} \mathrm{NPs}^{37}$. Interestingly, $\mathrm{TiO}_{2}$ at 100 and $200 \mathrm{mg} / \mathrm{L}$ concentrations actually reduced the CAT activity compared with the $\operatorname{control}^{49}$, indicating that ENP composition plays a role in the induction of oxidative stress in plants.

The POD activities in N. arvensis roots and shoots were elevated after exposure to both $\mathrm{Al}_{2} \mathrm{O}_{3}$ and NiO NPs. The POD activity in plant roots increased by 1.32 and 1.47 fold at 1000 and $2500 \mathrm{mg} / \mathrm{L}$ of $\mathrm{Al}_{2} \mathrm{O}_{3} \mathrm{NPs}(\mathrm{p}<0.05)$ compared to the control. Similarly, NiO NPs markedly increased the POD activity in plant root, with a 3.7 fold increase at $1000 \mathrm{mg} / \mathrm{L}$. Interestingly, $2500 \mathrm{mg} / \mathrm{L}$ of NiO NPs significantly decreased the POD activity in plant roots by $24 \%$ compared with the $1000 \mathrm{mg} / \mathrm{L}$ treatment $(\mathrm{P}<0.05)$. The enhancement of POD activity in plant shoot was relatively mild compared with that in plant roots. Treatment with 1000 and $2500 \mathrm{mg} / \mathrm{L} \mathrm{NiO} \mathrm{NPs}$ resulted in 1.9 and 2.2 fold increase of POD activity in plant shoots (Fig. 3B). In addition to reducing $\mathrm{H}_{2} \mathrm{O}_{2}$ accumulation during oxidative stress, POD also affects lignin and ethylene synthesis, as well as the decomposition of indole-3-acetic acid (IAA). It also involves in plant resistance against pathogens and wound healing ${ }^{48}$. The increase in POD 


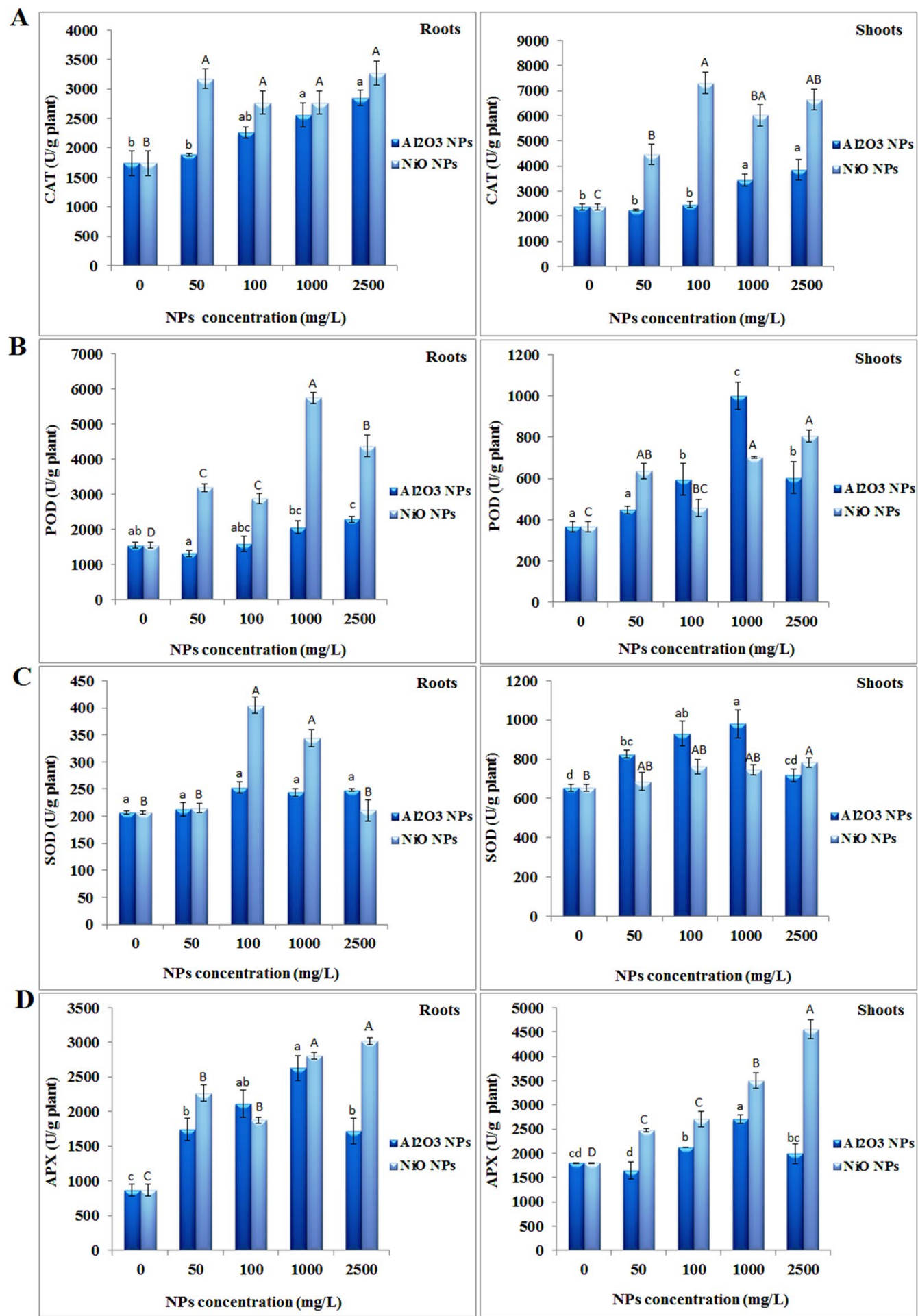

Figure 3. Effects of $\mathrm{Al}_{2} \mathrm{O}_{3}$ and $\mathrm{NiO}$ NPs treatment on antioxidative enzymes: (A) CAT, (B) POD, (C) SOD and (D) APX activity in the roots and shoots of N. arvensis.

activities against studied ENPs implies the protective ability of $N$. arvensis against oxidative stress. In agreement with our studies, increased POD activity in Glycine max and Cucumis sativus treated with CuO NPs, in Triticum aestivum treated with Ag NPs, and in Vicia narbonensis treated with $\mathrm{TiO}_{2}$ NPs was also reported ${ }^{23,45,50,51}$.

SOD plays an important role against ROS-mediated toxicity by catalyzing the dismutation of free hydroxyl radicals to $\mathrm{H}_{2} \mathrm{O}_{2}$ and $\mathrm{O}_{2} . \mathrm{Al}_{2} \mathrm{O}_{3}$ and $\mathrm{NiO}$ NPs displayed different effects on SOD activity in the shoots and roots of N. arvensis. The presence of $\mathrm{NiO} N P s$ up to $1000 \mathrm{mg} / \mathrm{L}$ increased the SOD activity in roots, but decreased the SOD activity at $2500 \mathrm{mg} / \mathrm{L}$ to a similar level in the control plant. The SOD activities in the shoots also increased with $\mathrm{NiO} N P s$, but the increase was significant only at the highest concentration of $2500 \mathrm{mg} / \mathrm{L}(\mathrm{p}<0.01)$. The addition 

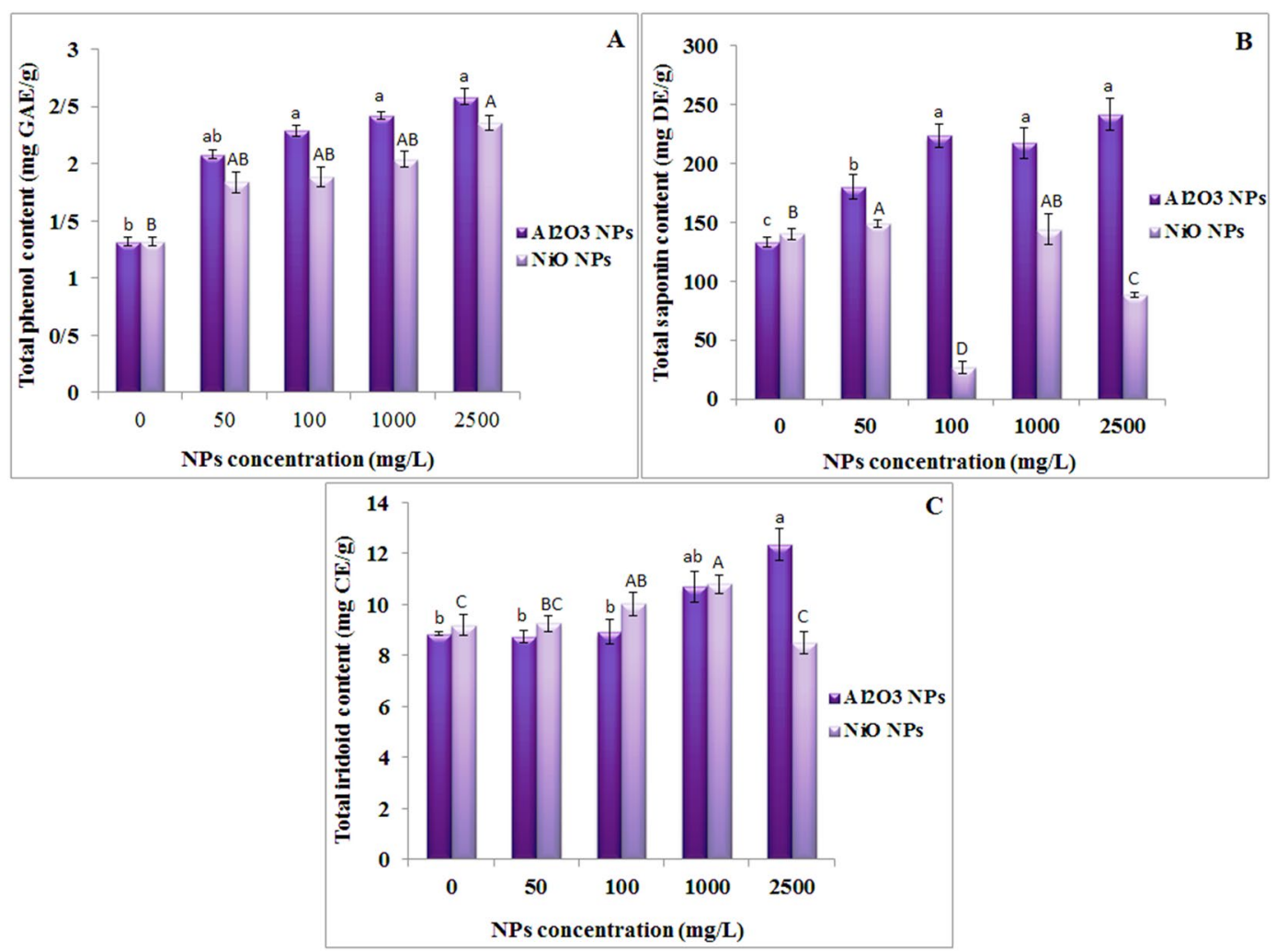

Figure 4. Effects of $\mathrm{Al}_{2} \mathrm{O}_{3}$ and $\mathrm{NiO}$ NPs treatment on secondary metabolites activity: (A) total phenols, (B) total saponins and $(\mathbf{C})$ total iridoids in shoots of $N$. arvensis.

of $\mathrm{Al}_{2} \mathrm{O}_{3} \mathrm{NPs}$ had no significant effects on SOD activities of $N$. arvensis roots. When $N$. arvensis was treated with $1000 \mathrm{mg} / \mathrm{L}$ of $\mathrm{Al}_{2} \mathrm{O}_{3} \mathrm{NPs}$, the SOD activity in plant shoots was significantly enhanced by $49 \%(\mathrm{p}<0.05)$, while $2500 \mathrm{mg} / \mathrm{L}$ of this ENP reduced shoot SOD activity by $27 \%(\mathrm{p}<0.01)$ compared with the $1000 \mathrm{mg} / \mathrm{L}$ treatment (Fig. 3C). Significant increase in SOD activity may be due to either direct effect of these ENPs on the SOD gene expression or an indirect effect mediated through an increase in the level of $\mathrm{O}_{2}{ }^{-}$radicals. Rajeshwari et al..$^{52}$ found similar impact of $\mathrm{Al}_{2} \mathrm{O}_{3}$ NPs on SOD activity in Allium cepa root tips and a maximum increase was found at $100 \mathrm{mg} / \mathrm{L}^{52}$. Feisal et al..$^{37}$ revealed that in NiO NPs treated tomato roots, SOD activity increased with increasing $\mathrm{NiO}$ NPs in comparison to control but its activity was decreased at 1500 and $2000 \mathrm{mg} / \mathrm{L} \mathrm{NiO} \mathrm{NPs} \mathrm{that} \mathrm{confirms}$ our results ${ }^{37}$. Therefore, reduced SOD activity in this study under the highest $\mathrm{Al}_{2} \mathrm{O}_{3}$ and NiO NPs concentrations may reflect the low ROS scavenging capacity and increased damage to plants ${ }^{11}$.

As a member of the ascorbic acid-glutathione cycle, APX plays a crucial role in eliminating hazardous $\mathrm{H}_{2} \mathrm{O}_{2}$ from plant cells. There was a progressive increase in APX activity with increasing NiO NPs in the shoots and roots of $N$. arvensis. The APX slightly increased with the increase of NiO NPs from $50-100 \mathrm{mg} / \mathrm{L}$, but substantially increased in 1000 and $2500 \mathrm{mg} / \mathrm{L} \mathrm{NiO} \mathrm{NPs} \mathrm{treated} \mathrm{plants.} \mathrm{In} \mathrm{plants} \mathrm{treated} \mathrm{with} 2500 \mathrm{mg} / \mathrm{L}$ of NiO NPs, APX activity in the roots and shoots of $N$. arvensis was 3.49 and 2.54 -fold of their respective controls $(0 \mathrm{mg} / \mathrm{L})$ (Fig. 3D). The APX activity in plants exposed to $\mathrm{Al}_{2} \mathrm{O}_{3} \mathrm{NPs}$ exhibited different patterns in comparison to its activity under $\mathrm{NiO}$ NPs exposure. The enzyme activities were increased gradually with increasing level of $\mathrm{Al}_{2} \mathrm{O}_{3}$ NPs, and reached the maximum at $1000 \mathrm{mg} / \mathrm{L}$. The APX activity decreased at the $\mathrm{Al}_{2} \mathrm{O}_{3} \mathrm{NPs}$ concentration of $2500 \mathrm{mg} / \mathrm{L}$ (Fig. 3D).

By comparing the activities of these four enzymatic antioxidants (CAT, POD, SOD and APX), it is evident that the accumulation of studied ENPs induced a strong antioxidant response in N. arvensis. Furthermore, these results showed differential responses of the antioxidant enzymes to different ENPs in different plant tissues, probably stemming from the different physico-chemical properties of these two ENPs such as their size, shape, surface chemistry.

Antioxidant compounds. Secondary metabolites such as the total phenols, saponins and iridoids were measured in the shoots of N. arvensis. Phenols as secondary metabolites of plants are known to be involved in the antioxidant activity in plants growing under heavy metal stress and are typically increased by metal stress ${ }^{53}$. Also, phenols are oxidized by peroxidase and play a role in scavenging $\mathrm{H}_{2} \mathrm{O}_{2}$ molecules ${ }^{54}$. In this study, both ENPs enhanced the total phenol contents in $N$. arvesis shoot compared with the control and there was no significant difference between the treatment groups of between $50-2500 \mathrm{mg} / \mathrm{L} \mathrm{NiO} \mathrm{NPs.} \mathrm{As} \mathrm{shown} \mathrm{in} \mathrm{Fig.} \mathrm{4A,} \mathrm{the} \mathrm{total}$ phenol content was significantly increased by $96 \%$ and $79 \%$ in the presence of $2500 \mathrm{mg} / \mathrm{L}_{\text {of }} \mathrm{Al}_{2} \mathrm{O}_{3}$ and NiO NPs respectively in comparison to the control plants. The effects were more pronounced in the shoots of $\mathrm{Al}_{2} \mathrm{O}_{3} \mathrm{NPs}_{\mathrm{s}}$ treated plants than NiO NPs treated plants (Fig. 4A). Similar effects were also recorded in Eichhornia crassipes $^{55}$ 

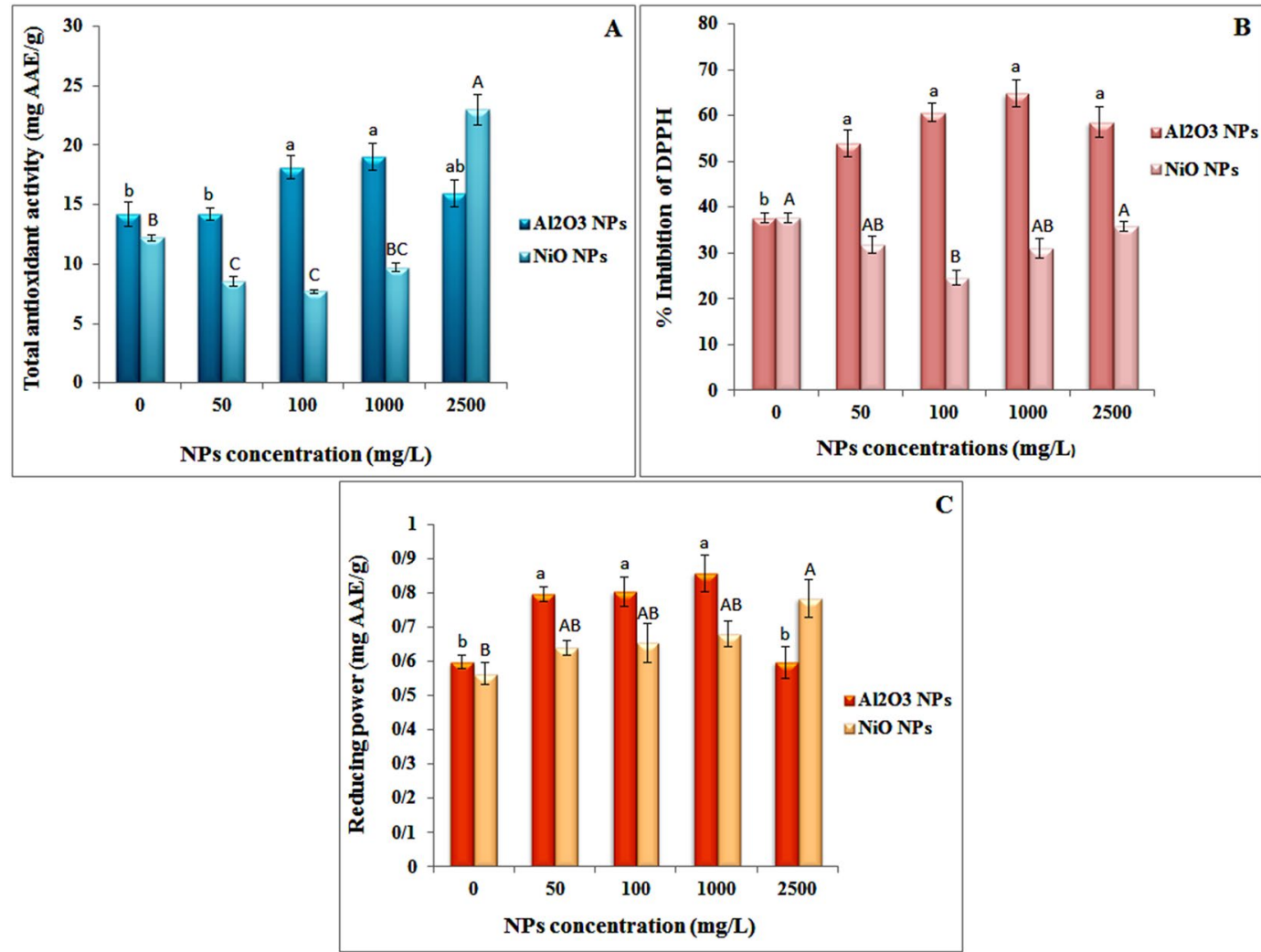

Figure 5. Effects of $\mathrm{Al}_{2} \mathrm{O}_{3}$ and $\mathrm{NiO} N$ ss treatments on antioxidant capacity: (A) total antioxidant, (B) DPPH scavenging, $(\mathbf{C})$ reducing power, in shoots of $N$. arvensis.

and Bacopa monnieri $i^{56}$ under Ag NPs, which supports the conviction that ENPs induce the production of total phenolic compounds in plants.

Saponin is a class of amphipathic glycosides, which have one or more hydrophilic glycoside moieties combined with a lipophilic triterpene derivative ${ }^{57}$. The total saponin content of plants treated with $\mathrm{Al}_{2} \mathrm{O}_{3}$ and $\mathrm{NiO} N P s$ at various concentrations is shown in Fig. $4 \mathrm{~B} . \mathrm{Al}_{2} \mathrm{O}_{3} \mathrm{NPs}$ significantly increased the total saponin production in $N$. arvensis at all tested concentrations, whereas its content dropped 5 and 1.6 times at 100 and $2500 \mathrm{mg} / \mathrm{L} \mathrm{NiO} \mathrm{NPs,}$ compared with the control. This result agrees with a previous report that low concentrations of Ag NPs increased total saponin content in Calendula officinalis ${ }^{58}$, but higher Ag NPs $(0.8$ to $1.6 \mathrm{mM})$ decreased the total saponin content in the same plant.

Iridoids are a type of monoterpenes, which are typically found in plants as glycosides, often bound to glucose. The iridoids produced by plants act primarily as a defense against biotic and abiotic stresses. A marked increase (39\% compared with controls, Fig. 4C) in total iridoids concentration was observed in plant shoots treated with $2500 \mathrm{mg} / \mathrm{L} \mathrm{Al}_{2} \mathrm{O}_{3} \mathrm{NPs}$. However, shoot iridoids content steadily increased in the presence of up to $1000 \mathrm{mg} / \mathrm{L} \mathrm{NiO}$ NPs before decreased in plants treated with $2500 \mathrm{mg} / \mathrm{L} \mathrm{NiO} \mathrm{NPs.}$

Total antioxidant capacity, DPPH scavenging and reducing power activities. The total antioxidant capacity of $N$. arvensis exposed to both ENPs is shown in Fig. 5A. The total antioxidant activity increased significantly at 100 and $1000 \mathrm{mg} / \mathrm{L} \mathrm{Al} \mathrm{O}_{3}$ NPs. Plant exposure to $0-1000 \mathrm{mg} / \mathrm{L}$ of NiO NPs resulted in a decrease of the total antioxidant capacity compared with plants grown in ENPs-free medium (Fig. 5A). By contrast, the total antioxidant capacity was significantly increased at $2500 \mathrm{mg} / \mathrm{L} \mathrm{NiO} \mathrm{NPs} \mathrm{(88.5 \%} \mathrm{increase} \mathrm{over} \mathrm{control).}$

In this study, DPPH free radical scavenging activity in shoot of N. arvensis exposed to NiO NPs increased with increasing $\mathrm{NiO}$ NPs concentrations after three weeks of treatment (Fig. 5B). When $N$. arvensis was exposed to $200 \mu \mathrm{L}$ of $2500 \mathrm{mg} / \mathrm{L}$ of NiO NPs, the DPPH free radical scavenging activity reached the maximum of $35.79 \%$ of inhibition (Fig. $5 \mathrm{~B}$ ). This result implies that $N$. arvensis has a high capability to cope with the oxidative stress induced by NiO NPs. In plants exposed to $\mathrm{Al}_{2} \mathrm{O}_{3} \mathrm{NPs}$, DPPH scavenging activity increased in different levels with increasing $\mathrm{Al}_{2} \mathrm{O}_{3} \mathrm{NPs}$ concentrations from 50 to $1000 \mathrm{mg} / \mathrm{L}$ (Fig. 5B). The highest DPPH free radical scavenging activity in plant shoot was 4.93 fold of the control at $1000 \mathrm{mg} / \mathrm{L} \mathrm{Al} \mathrm{O}_{3} \mathrm{NPs}$. The DPPH free radical scavenging activity were decreased by $17 \%$ in extracts containing $2500 \mathrm{mg} / \mathrm{L}$ of $\mathrm{Al}_{2} \mathrm{O}_{3} \mathrm{NPs}$ compared with $1000 \mathrm{mg} / \mathrm{L}$ treated plants. Similar to our results, Khan et al..$^{59}$ evaluated the effects of nine types of metal ENPs including monometallic and bimetallic alloy ENPs such as $\mathrm{AgCu}, \mathrm{AuCu}$ and $\mathrm{AgAu}$ on DPPH free radical scavenging activity of Silybum marianum $^{58}$. They showed an increase in DPPH percentage after 28 days of exposure for all ENPs suspensions. Javed et al..$^{60}$ demonstrated that DPPH free radical scavenging activity in Stevia rebaudiana Bertoni shoots was $74.8 \%$ and $68.6 \%$ higher under $10 \mathrm{mg} / \mathrm{L}$ and $1 \mathrm{mg} / \mathrm{L} \mathrm{ZnO} \mathrm{NPs} \mathrm{treatments}{ }^{60}$. Their results also showed that the 
lowest antioxidant activities were obtained from extracts containing $1000 \mathrm{mg} / \mathrm{L} \mathrm{ZnO}$ NPs in MS medium, which can be related to the toxic effects of this treatment by generating oxidative stress and imbalance of anti-oxidative activities ${ }^{60}$.

The reduction of Fe (III) is often used as an indicator of electron-donating activity, an important process in phenolic antioxidant reaction ${ }^{61}$. The presence of reductant (antioxidant) in the plant extracts causes the reduction of the $\mathrm{Fe}^{3+}$ /ferricyanide complex to the ferrous form. Therefore, the concentration of $\mathrm{Fe}^{2+}$ was monitored by measuring the formation of Perl's Prussian blue at $700 \mathrm{~nm}^{62}$. In this study, the total reducing power of plants exposed to both $\mathrm{Al}_{2} \mathrm{O}_{3}$ and NiO NPs was affected similarly as the DPPH free radical scavenging activity (Fig. 5C). Although these effects were mostly not statistically significant $(p>0.05)$, there were significant $(p<0.05)$ increases in the total reducing power of shoot extract treated with $1000 \mathrm{mg} / \mathrm{L}$ of $\mathrm{Al}_{2} \mathrm{O}_{3}$ NPs (by $43 \%$ ) and those treated with $2500 \mathrm{mg} / \mathrm{L}$ of $\mathrm{NiO} \mathrm{NPs}$ (by $32 \%$ ) when compared to the control plants. Therefore, with $\mathrm{Al}_{2} \mathrm{O}_{3} \mathrm{NPs}$ treatments, the lowest antioxidant activities were obtained from extracts containing $2500 \mathrm{mg} / \mathrm{L} \mathrm{NPs} \mathrm{treatments,}$ which also had lower DPPH free radical scavenging activity and total reducing power activity than the control group.

\section{Conclusion}

In summary, this study demonstrated the concentration dependent effects of $\mathrm{NiO}$ and $\mathrm{Al}_{2} \mathrm{O}_{3} \mathrm{NPs}$ on the growth and antioxidant activities of $N$. arvensis. NiO NPs exhibited greater effects than $\mathrm{Al}_{2} \mathrm{O}_{3} \mathrm{NPs}$ on N. arvensis growth. Significantly enhanced activities of antioxidant enzymes (CAT, POD, APX and SOD) and antioxidant compounds (total iridoids, total saponin, and total phenolic) along with DPPH scavenging activity, total antioxidant capacity and total reducing power were observed in plants treated with 50 to $1000 \mathrm{mg} / \mathrm{L}$ of NiO and $\mathrm{Al}_{2} \mathrm{O}_{3} \mathrm{NPs}$ in hydroponic systems. However, adverse effects of $\mathrm{NiO}$ and $\mathrm{Al}_{2} \mathrm{O}_{3} \mathrm{NPs}$ on these phytochemical assays appeared when Hoagland medium was supplemented with 1000 or $2500 \mathrm{mg} / \mathrm{L}$ of $\mathrm{NiO}$ and $\mathrm{Al}_{2} \mathrm{O}_{3} \mathrm{NPs}$. The concentration and composition-dependent responses of plants observed in this study provide new insights into the effects of ENPs in the mineral nutrition, antioxidant activities and alteration of metabolic pathways of medicinal plants.

\section{Materials and Methods}

Nanomaterials, chemicals and seeds. $\quad \mathrm{Al}_{2} \mathrm{O}_{3}$ and $\mathrm{NiO}$ NPs were purchased from Iranian Nanomaterial Company. According to the supplier, the diameter of NiO NPs fell in the range 5-8 nm. Most NiO NPs were spherical and has the purity of $99.5 \%$. The specific surface area was in the range of $50-100 \mathrm{~m}^{2} / \mathrm{g}$. The average diameter of $\mathrm{Al}_{2} \mathrm{O}_{3} \mathrm{NPs}$ was about $5 \mathrm{~nm}$. The purity of $\mathrm{Al}_{2} \mathrm{O}_{3} \mathrm{NPs}$ was $99.99 \%$ and its specific surface area was 150 $\mathrm{m}^{2} / \mathrm{g}$. Seeds of $N$. arvensis were purchased from Pakanbazr Company (Isfahan, Iran).

Preparation of particles and cultures. Seeds of N. arvensis were sterilized for $10 \mathrm{~min}$ in $10 \%$ sodium hypochlorite solution before germination. They were germinated on sand soaked with 0.1 strength modified

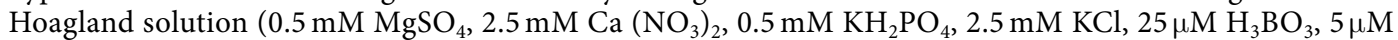
$\mathrm{MnSO}_{4}, 0.4 \mu \mathrm{M} \mathrm{ZnSO}_{4}, 0.2 \mu \mathrm{M} \mathrm{CuSO}_{4}, 0.25 \mu \mathrm{M} \mathrm{Na}_{2} \mathrm{MoO}_{4}, 50 \mu \mathrm{M}$ Fe-EDTA, pH 5.5). After 10 days, the solution was replaced with Hoagland solutions containing different concentrations of $\mathrm{Al}_{2} \mathrm{O}_{3}$ or $\mathrm{NiO} \mathrm{NPs}(0,50,100,1000$ and $2500 \mathrm{mg} / \mathrm{L})$. Prior to the replacement, the ENP suspensions $(100 \mathrm{~mL})$ were first sonicated in an ultrasonic water-bath for $90 \mathrm{~min}$. All experiments were carried out in a greenhouse under semi-controlled conditions: day/ night photoperiod $(16 / 8 \mathrm{~h})$, a light intensity of $100 \mu \mathrm{M} / \mathrm{m}^{2} / \mathrm{s}$, day/night temperature $\left(24 / 20 \pm 1{ }^{\circ} \mathrm{C}\right)$ and day/night relative humidity $(70 / 75 \%)$. Hydroponic system was adopted for this study to avoid the compounding effect of soil particles and microorganisms in soil on the physiological effect of chosen nanoparticles. In addition, hydroponic system is gain popularity in urban agriculture for vegetable growth due to dwindling global arable lands. Therefore, the results hold great importance for sustainable applications of nanotechnology in agriculture. A wide range of concentrations are used for both ENPs so that the physiological responses of plants in the presence of mild to severe contamination can be investigated. All treatments had three replicates and the experiment lasted for three weeks. Afterwards, the plants were harvested, and rinsed with tap water. The shoot and root biomass were measured after they were oven dried at $65^{\circ} \mathrm{C}$ for three days.

Hydrogen peroxide $\left(\mathrm{H}_{2} \mathrm{O}_{2}\right)$ content. Hydrogen peroxide level was measured following the method described by Sergiev et al. ${ }^{63}$. Fresh roots or shoots $(0.5 \mathrm{~g})$ were homogenized in ice bath with $5 \mathrm{~mL}$ of $0.1 \%(\mathrm{~W} / \mathrm{V})$ trichloroacetic acid (TCA). The mixtures were centrifuged at $12,000 \mathrm{~g}$ for $15 \mathrm{~min} .0 .5 \mathrm{~mL}$ of the obtained supernatant was added to the mixture containing $0.5 \mathrm{~mL}$ of potassium phosphate buffer $(10 \mathrm{mM}, \mathrm{pH} 7.0)$ and $1 \mathrm{~mL}$ of $\mathrm{KI}$ solution (1 M). The content of $\mathrm{H}_{2} \mathrm{O}_{2}$ was determined with a spectrophotometer (Bausch \& Lomb 70) at $390 \mathrm{~nm}$.

Enzyme extractions and assays. To prepare extracts for the analysis of enzyme activities, fresh plant tissues were ground to fine powders in liquid nitrogen and extracted at a ratio 1:3 (w/v) fresh weight to extraction buffer containing $1 \mathrm{mM}$ EDTA, $3 \mathrm{mM}$ DTT and 5\% PVP. The homogenate thus obtained was centrifuged for $20 \mathrm{~min}$ at $14,000 \mathrm{rpm}$ and the supernatant was either used for enzyme assays or protein extraction, which is described below in details.

Catalase (CAT) activity. Catalase activity was determined according to Aebi's (1984) method ${ }^{64} \cdot 0.1 \mathrm{~mL}$ of enzyme extract was mixed with $2.9 \mathrm{~mL}$ of $50 \mathrm{mM}$ phosphate buffer ( $\mathrm{pH}$ 7.0) containing $30 \mathrm{mM} \mathrm{H}_{2} \mathrm{O}_{2}$ to make a total volume of $3 \mathrm{~mL}$. CAT activity was estimated based on the decreased absorbance of $\mathrm{H}_{2} \mathrm{O}_{2}$ at $240 \mathrm{~nm}$ (Shimadzu-UV mini- 1240). The CAT activity was determined based on the molar extinction coefficient of $\mathrm{H}_{2} \mathrm{O}_{2}$ $\left(39.4 \mathrm{M}^{-1} \mathrm{~cm}^{-1}\right)$ and is expressed as $\mu \mathrm{M} \mathrm{H}_{2} \mathrm{O}_{2}$ per mg fresh weight per min. 
Ascorbate peroxidase (APX) activity. Ascorbate peroxidase was assayed based on the method reported by Nakano and Asada $(1981)^{65}$. The reaction complex contained potassium phosphate $(50 \mathrm{mM}, \mathrm{pH} 7.0)$, EDTA $(0.2 \mathrm{mM})$, ascorbic acid $(0.5 \mathrm{mM}), 2 \% \mathrm{H}_{2} \mathrm{O}_{2}$, and $100 \mu \mathrm{L}$ of enzyme extract with a total volume of $3 \mathrm{~mL}$. A reduction of absorbance (at $290 \mathrm{~nm}$ for $1 \mathrm{~min}$ ) was recorded. The activity of enzyme was estimated using the extinction coefficient of $2.8 \mathrm{mM}^{-1} \mathrm{~cm}^{-1}$. One unit APX activity was defined as $1 \mathrm{mM}$ ascorbate oxidized per $\mathrm{mL}$ per min at $25^{\circ} \mathrm{C}$.

Peroxidase (POD) activity. Peroxidase activity was measured using the guaicol oxidation method of Chance and Machly $(1955)^{66}$. The reaction mixture ( $3 \mathrm{~mL}$ in final volume) contains potassium phosphate buffer $(10 \mathrm{mM}, \mathrm{pH}$ 7.0), guaicol $(8 \mathrm{mM})$ and $100 \mu \mathrm{L}$ enzyme extract. The reaction was initiated by adding $10 \mu \mathrm{L}$ of $40 \mathrm{mM} \mathrm{H}_{2} \mathrm{O}_{2}$. The absorbance was determined spectrophotometerically (Bausch \& Lomb 70) within $1 \mathrm{~min}$ at $470 \mathrm{~nm}$. POD activity was calculated using the extinction coefficient of $26.6 \mathrm{mM}^{-1} \mathrm{~cm}^{-1}$.

Superoxide Dismutase (SOD) activity. Superoxide dismutase activity was determined following the Giannopolitis and Ries (1977) protocol by spectrophotometer method ${ }^{67}$. In this method, reaction solution contained $13 \mathrm{mM}$ methionine, $75 \mu \mathrm{M}$ nitroblue tetrazolium (NBT), $2 \mu \mathrm{M}$ riboflavin, $50 \mathrm{mM}$ phosphate buffer $(\mathrm{pH}=$ 7.8) and $0-50 \mu \mathrm{L}$ of extracted enzyme. Reaction was started by placing the tubes against two fluorescent lamps $(15 \mathrm{~W})$. The reaction was terminated after $10 \mathrm{~min}$ by turning off the lamps. Absorption was measured at $560 \mathrm{~nm}$ with a spectrophotometer (Bausch \& Lomb 70). The illuminated and non-illuminated reactions without supernatant were placed as calibration standards. Ultimately, one unit of enzyme activity was equivalent to the amount of the enzyme needed for $50 \%$ reduction of the NBT photochemical reaction.

Preparation of extract and antioxidant assays. N. arvensis leaf extracts were prepared by drying and then grounding leaves from plants exposed to various concentrations of ENPs. One gram of leaf powder from each treatment was ground and extracted by $3 \mathrm{ml}$ of acidic methanol reagent (99:1 methanol: $\mathrm{HCl}$ ) in $25^{\circ} \mathrm{C}$ for $24 \mathrm{~h}$ and the extract was centrifuged at $10,000 \mathrm{rpm}$ for $15 \mathrm{~min}$. The supernatant was collected and then stored in an airtight container in the refrigerator $\left(4^{\circ} \mathrm{C}\right)$ for the measurement of all antioxidant compounds. The spectrophotometric assays were performed in triplicates.

Determination of total phenolic content. The total phenols were determined based on the FolinCiocalteu method ${ }^{68}$. An aliquot $(0.5 \mathrm{~mL})$ of plant extract $(1 \mathrm{mg} / \mathrm{mL})$ was mixed with $2.5 \mathrm{~mL}$ of Folin-Ciocalteu reagent (diluted $1: 10$ ) and $2 \mathrm{~mL}$ of $\mathrm{NaHCO}_{3}(7.5 \%)$. Then, the test solution was maintained at $45^{\circ} \mathrm{C}$ for $15 \mathrm{~min}$. The absorbance was recorded at $765 \mathrm{~nm}$ with a spectrophotometer (Bausch \& Lomb 70) against a blank sample. Total phenols were determined as Gallic acid (standard) equivalents (mg GA/g extract).

Total saponins assay. Total saponin contents in leaves were estimated using the colorimetric method reported by Hiai et al. ${ }^{69}$ with minor modifications ${ }^{69} .50 \mu \mathrm{L}$ of plant extract was added to different test tubes containing $0.25 \mathrm{~mL}$ of vanillin reagent $(8 \% \mathrm{w} / \mathrm{v}$ in ethanol $99.9 \%)$. Those test tubes were placed in ice-cold water bath and $2.5 \mathrm{~mL}$ of $72 \%(\mathrm{v} / \mathrm{v})$ sulfuric acid was slowly added to each tube. After $3 \mathrm{~min}$, the tubes were heated to $60^{\circ} \mathrm{C}$ for $10 \mathrm{~min}$ using a water bath and then cooled to room temperature. Absorbance was measured at $544 \mathrm{~nm}$ using a spectrophotometer against the reagent blank. Diosgenin was used as a standard and the content of total saponins was expressed as Diosgenin equivalents ( $\mathrm{mg} \mathrm{DE} / \mathrm{g}$ extract).

Estimation of total iridoid content. The total iridoid content was determined according to the colorimetric method described by Haag-Berrurier et al ${ }^{70}$ with slight modifications ${ }^{70}$. A $100 \mu \mathrm{L}$ aliquot of plant extract solution was incubated with $900 \mu \mathrm{L}$ of reagent solution containing $82 \mathrm{~mL}$ methanol, $100 \mathrm{mg}$ vanillin and $8 \mathrm{~mL}$ concentrated sulfuric acid. Absorbance was read spectrophotometrically at $538 \mathrm{~nm}$. Catalpol was used as a standard compound for the establishment of the calibration curve. Total iridoids was expressed as Catalpol equivalents (mg CE/g extract).

Total antioxidant capacity. The capacity of total antioxidant of the methanolic extracts of samples was determined using a previously reported method by Prieto et al..$^{71}$ with slight modifications ${ }^{71}$. An aliquot of $0.3 \mathrm{~mL}$ of sample extracts solution was mixed with $2.7 \mathrm{~mL}$ of reagent solution containing sulfuric acid $(0.6 \mathrm{M})$, sodium phosphate $(28 \mathrm{mM})$ and ammonium molybdate $(4 \mathrm{mM})$. The tubes containing reaction solution were incubated at $95^{\circ} \mathrm{C}$ for $90 \mathrm{~min}$ and then cooled to room temperature. All samples were run in triplicates and their absorbance was read at $695 \mathrm{~nm}$ by a spectrophotometer. The standard reference was ascorbic acid and the total antioxidant capacity was expressed as mg of ascorbic acid equivalent per gram of the dry extract.

DPPH radical scavenging activity analyze. The free radical scavenging activity of plants was calculated using the method described by Sarker ${ }^{72}$. Briefly, serial dilutions were carried out with the stock solution $(1 \mathrm{mg} / \mathrm{mL})$ of the extracts. Diluted solutions ( $1 \mathrm{~mL}$ of each samples) were reacted with $1 \mathrm{~mL}$ of a freshly prepared DPPH (2,2-diphenyl-1-picryl hydrazyl) methanol solution $(80 \mu \mathrm{g} / \mathrm{mL})$ for $30 \mathrm{~min}$ in the dark at room temperature. Absorbance values of these solutions were determined with a spectrophotometer at $517 \mathrm{~nm}$. Methanol was used as a blank. Control sample was prepared containing the same amount of methanol and DPPH without test compounds. Inhibitions of DPPH radical in percent (I\%) were estimated as follow:

$$
\mathrm{I} \%=\left[\left(\mathrm{A}_{\text {Control }}-\mathrm{A}_{\text {sample }}\right) / \mathrm{A}_{\text {Control }}\right] \times 100
$$

where $\mathrm{A}_{\text {Control }}$ is defined as the absorbance of the control reaction (comprising all reagents without the test compound) and $\mathrm{A}_{\text {sample }}$ is the absorbance of the test compounds. 
Reducing power activity. Total reducing power activity of samples was investigated according to the method described by Aman et al. ${ }^{73}$ with slight modifications ${ }^{73}$. An aliquot of $2.5 \mathrm{~mL}$ of stock solution of each sample was mixed with phosphate buffer $(2.5 \mathrm{~mL}, 0.2 \mathrm{M}, \mathrm{PH} 6.6)$ and potassium ferricyanide $(2.5 \mathrm{~mL}, 1 \%)$. The tubes containing the reaction solutions were then incubated at $50^{\circ} \mathrm{C}$ for $20 \mathrm{~min}$. Afterwards, $2.5 \mathrm{~mL}$ of $10 \%$ trichloroacetic acid was added to each tube and then $2.5 \mathrm{~mL}$ of the reaction mixture was mixed with distilled water $(2.5 \mathrm{~mL})$ and ferric chloride $(0.5 \mathrm{~mL}, 0.1 \%)$. The absorbance of samples was measured at $700 \mathrm{~nm}$ with a spectrophotometer. Ascorbic acid was used as a positive control and the results were expressed as mg ascorbic acid equivalent per gram.

Statistical analysis. The data represent mean of three replicates \pm standard error (S.E). One-way ANOVA was employed to confirm the variability of data and validity of results with different rates of NPs addition. Duncan's multiple range test (DMRT) was employed to determine the significant differences between treatments to a significance level of $\mathrm{P}<0.05$ or very significant as $\mathrm{P} \leq 0.001$. Statistical analyses were performed using SPSS (24) software.

\section{Data availability}

All data generated or analyzed during this study are included in this published article (and its Supplementary Information files).

Received: 26 September 2019; Accepted: 18 February 2020;

Published online: 02 March 2020

\section{References}

1. Scrinis, G. \& Lyons, K. The emerging nano-corporate paradigm: nanotechnology and the transformation of nature, food and agrifood systems. Int. J. Sociol. Agr. Food 15, 22-44 (2007).

2. Nel, A., Xia, T., Mädler, L. \& Li, N. Toxic potential of materials at the nanolevel. Science 311, 622-627 (2006).

3. Thwala, M., Klaine, S. J. \& Musee, N. Interactions of metal-based engineered nanoparticles with aquatic higher plants: A review of the state of current knowledge. Environ. Toxicol. Chem (2016).

4. Hashimoto, Y., Takeuchi, S., Mitsunobu, S. \& Ok, Y.-S. Chemical speciation of silver (Ag) in soils under aerobic and anaerobic conditions: Ag nanoparticles vs. ionic Ag. J. Hazard. Mater. 322, 318-324 (2017).

5. Yanı, F. \& Vardar, F. Toxic effects of aluminum oxide $\left(\mathrm{Al}_{2} \mathrm{O}_{3}\right)$ nanoparticles on root growth and development in Triticum aestivum. Water. Air. Soil. Pollut 226, 296 (2015)

6. Pittol, M., Tomacheski, D., Simões, D. N., Ribeiro, V. F. \& Santana, R. M. C. Macroscopic effects of silver nanoparticles and titanium dioxide on edible plant growth. Environ. Nanotechnol. Monit. Manage 8, 127-133 (2017).

7. Sharon, M., Choudhary, A. K. \& Kumar, R. Nanotechnology in agricultural diseases and food safety. J. Phytol 2 (2010).

8. Khot, L. R., Sankaran, S., Maja, J. M., Ehsani, R. \& Schuster, E. W. Applications of nanomaterials in agricultural production and crop protection: a review. Crop Prot 35, 64-70 (2012).

9. Sekhon, B. S. Nanotechnology in agri-food production: an overview. Nanotechnol. Sci. Appl 7, 31-53 (2014).

10. Manjunatha, S., Biradar, D. \& Aladakatti, Y. Nanotechnology and its applications in agriculture: A review. J. Farm. Sci 29, 1-13 (2016).

11. Hatami, M. \& Ghorbanpour, M. Defense enzyme activities and biochemical variations of Pelargonium zonale in response to nanosilver application and dark storage. Turk. J. Biol 38, 130-139 (2014).

12. Melegari, S. P., Perreault, F., Costa, R. H. R., Popovic, R. \& Matias, W. G. Evaluation of toxicity and oxidative stress induced by copper oxide nanoparticles in the green alga Chlamydomonas reinhardtii. Aquat. Toxicol 142, 431-440 (2013).

13. Rico, C., Peralta-Videa, J. \& Gardea-Torresdey, J. In Nanotechnology and Plant Sciences 1-17 (Springer, 2015)

14. Ma, C., White, J. C., Dhankher, O. P. \& Xing, B. Metal-based nanotoxicity and detoxification pathways in higher plants. Environ. Sci. Technol 49, 7109-7122 (2015)

15. Du, W. et al. Interaction of metal oxide nanoparticles with higher terrestrial plants: Physiological and biochemical aspects. Plant Physiol. Biochem (2016).

16. Rai, P. K. et al. Nanoparticle-plant interaction: Implications in energy, environment, and agriculture. Environ. Int 119, 1-19 (2018).

17. Ma, Y. et al. Origin of the different phytotoxicity and biotransformation of cerium and lanthanum oxide nanoparticles in cucumber. Nanotoxicol 9, 262-270 (2015).

18. Ma, X., Wang, Q., Rossi, L. \& Zhang, W. Cerium Oxide Nanoparticles and Bulk Cerium Oxide Leading to Different Physiological and Biochemical Responses in Brassica rapa. Environ. Sci. Technol (2015).

19. Zhao, L. et al. Stress response and tolerance of Zea mays to $\mathrm{CeO}_{2}$ nanoparticles: cross talk among $\mathrm{H}_{2} \mathrm{O}_{2}$, heat shock protein, and lipid peroxidation. ACS nano 6, 9615-9622 (2012).

20. Rico, C. M. et al. Cerium oxide nanoparticles modify the antioxidative stress enzyme activities and macromolecule composition in rice seedlings. Environ. Sci. Technol 47, 14110-14118 (2013).

21. Rico, C. M. et al. Effect of cerium oxide nanoparticles on rice: a study involving the antioxidant defense system and in vivo fluorescence imaging. Environ. Sci. Technol 47, 5635-5642 (2013).

22. Hu, C., Liu, X., Li, X. \& Zhao, Y. Evaluation of growth and biochemical indicators of Salvinia natans exposed to zinc oxide nanoparticles and zinc accumulation in plants. Environ. Sci. Pollut. Res 21, 732-739 (2014).

23. Kim, S., Lee, S. \& Lee, I. Alteration of phytotoxicity and oxidant stress potential by metal oxide nanoparticles in Cucumis sativus. Water, Air, Soil Pollut 223, 2799-2806 (2012).

24. Handy, R. D., Owen, R. \& Valsami-Jones, E. The ecotoxicology of nanoparticles and nanomaterials: current status, knowledge gaps, challenges, and future needs. Ecotoxicol 17, 315-325 (2008).

25. Jakubiak, M., Giska, I., Asztemborska, M. \& Bystrzejewska-Piotrowska, G. Bioaccumulation and biosorption of inorganic nanoparticles: factors affecting the efficiency of nanoparticle mycoextraction by liquid-grown mycelia of Pleurotus eryngii and Trametes versicolor. Mycol. Prog 13, 525-532 (2014).

26. Stanley, J. K., Coleman, J. G., Weiss, C. A. \& Steevens, J. A. Sediment toxicity and bioaccumulation of nano and micron-sized aluminum oxide. Environ. Toxicol. Chem 29, 422-429 (2010).

27. Hanemann, T. \& Szabó, D. V. Polymer-nanoparticle composites: from synthesis to modern applications. Materials 3, 3468-3517 (2010).

28. Schrand, A. M. et al. Metal-based nanoparticles and their toxicity assessment. Wiley Interdiscip Rev. Nanomed. Nanobiotechnol 2, 544-568 (2010).

29. Sadiq, I. M., Pakrashi, S., Chandrasekaran, N. \& Mukherjee, A. Studies on toxicity of aluminum oxide $\left(\mathrm{Al}_{2} \mathrm{O}_{3}\right)$ nanoparticles to microalgae species: Scenedesmus sp. and Chlorella sp. J. Nanopart. Res 13, 3287-3299 (2011). 
30. Burklew, C. E., Ashlock, J., Winfrey, W. B. \& Zhang, B. Effects of aluminum oxide nanoparticles on the growth, development, and microRNA expression of tobacco (Nicotiana tabacum). PloS one 7, e34783 (2012).

31. Riahi-Madvar, A., Rezaee, F. \& Jalali, V. Effects of alumina nanoparticles on morphological properties and antioxidant system of Triticum aestivum. Iran. J. Plant Physiol 3, 595-603 (2012).

32. Lee, C. W. et al. Developmental phytotoxicity of metal oxide nanoparticles to Arabidopsis thaliana. Environ. Toxicol. Chem 29, 669-675 (2010)

33. Lin, D. \& Xing, B. Phytotoxicity of nanoparticles: inhibition of seed germination and root growth. Environ Pollut 150, 243-250 (2007).

34. Salimi, A., Sharifi, E., Noorbakhsh, A. \& Soltanian, S. Direct electrochemistry and electrocatalytic activity of catalase immobilized onto electrodeposited nano-scale islands of nickel oxide. Biophys. Chem 125, 540-548 (2007).

35. Venkateswara Rao, K. \& Sunandana, C. Effect of fuel to oxidizer ratio on the structure, micro structure and EPR of combustion synthesized NiO nanoparticles. J. Nanosci. Nanotechnol 8, 4247-4253 (2008).

36. Magaye, R. \& Zhao, J. Recent progress in studies of metallic nickel and nickel-based nanoparticles' genotoxicity and carcinogenicity. Environ. Toxicol. Pharmacol 34, 644-650 (2012).

37. Faisal, M. et al. Phytotoxic hazards of NiO-nanoparticles in tomato: a study on mechanism of cell death. J. Hazard. Mater 250, 318-332 (2013).

38. Oukarroum, A., Barhoumi, L., Samadani, M. \& Dewez, D. Toxic effects of nickel oxide bulk and nanoparticles on the aquatic plant Lemna gibba L. Biomed. Res. Int 2015 (2015).

39. Marbut, M. M., Al-Kadhi, N. A. S. \& Al-Mzaein, K. A. Extraction of Flavonoid compounds from Nigella Arvensis Linn seeds \& to study their physiological effects on female reproductive system. Tikrit Med. J 13, 64-69 (2007).

40. Facciola, S. Cornucopia: a source book of edible plants. (1990).

41. Asztemborska, M., Steborowski, R., Kowalska, J. \& Bystrzejewska-Piotrowska, G. Accumulation of aluminium by plants exposed to nano-and microsized particles of $\mathrm{Al}_{2} \mathrm{O}_{3}$. Int. J. Environ. Res 9, 109-116 (2015).

42. Anane, R. \& Creppy, E. Lipid peroxidation as pathway of aluminium cytotoxicity in human skin fibroblast cultures: prevention by superoxide dismutase + catalase and vitamins E and C. Hum. Exp. Toxicol 20, 477-481 (2001).

43. Rao, K. S. J. \& Stein, R. First evidence on induced topological changes in supercoiled DNA by an aluminium D-aspartate complex. JBIC J. Biol. Inorg. Chem 8, 823-830 (2003).

44. Pakrashi, S. et al. Cytotoxicity of aluminium oxide nanoparticles towards fresh water algal isolate at low exposure concentrations. Aquat. Toxicol 132, 34-45 (2013).

45. Castiglione, M. R., Giorgetti, L., Cremonini, R., Bottega, S. \& Spanò, C. Impact of $\mathrm{TiO}_{2}$ nanoparticles on Vicia narbonensis $\mathrm{L}$.: potential toxicity effects. Protoplasma. 251, 1471-1479 (2014).

46. Zeng, D. \& Zhao, H. Activity test and mechanism study of an environmentally friendly wheat seed coating agent. Agric Sci 4, 334 (2013).

47. Mittler, R. Oxidative stress, antioxidants and stress tolerance. Trends Plant Sci 7, 405-410 (2002).

48. Song, G. et al. Effects of CuO nanoparticles on Lemna minor. Bot Stud 57, 1-8, https://doi.org/10.1186/s40529-016-0118-x (2016).

49. Laware, S. \& Raskar, S. Effect of titanium dioxide nanoparticles on hydrolytic and antioxidant enzymes during seed germination in onion. Int. J. Curr. Microbiol. App. Sci 3, 749-760 (2014).

50. Nair, P. M. G. \& Chung, I. M. A mechanistic study on the toxic effect of copper oxide nanoparticles in soybean (Glycine max L.) root development and lignification of root cells. Biol. Trace Elem. Res 162, 342-352 (2014).

51. Barbasz, A., Kreczmer, B. \& Oćwieja, M. Effects of exposure of callus cells of two wheat varieties to silver nanoparticles and silver salt $\left(\mathrm{AgNO}_{3}\right)$. Acta. Physiol. Plant 38, 1-11 (2016).

52. Rajeshwari, A. et al. Cytotoxicity of aluminum oxide nanoparticles on Allium cepa root tip-effects of oxidative stress generation and biouptake. Environ Sci. Pollut Res 22, 11057-11066 (2015).

53. Dudjak, J., Lachman, J., Miholová, D., Kolihová, D. \& Pivec, V. Effect of cadmium on polyphenol content in young barley plants (Hordeum vulgare L.). Plant Soil Environ 50, 471-477 (2004).

54. Singh, Y. \& Malik, C. Phenols and their antioxidant activity in Brassica juncea seedlings growing under $\mathrm{HgCl}_{2}$. stress. J. Microbiol. Biotech. Res 1, 124-130 (2011).

55. Rani, P. U., Yasur, J., Loke, K. S. \& Dutta, D. Effect of synthetic and biosynthesized silver nanoparticles on growth, physiology and oxidative stress of water hyacinth: Eichhornia crassipes (Mart) Solms. Acta. Physiol. Plant 38, 1-9 (2016).

56. Krishnaraj, C. et al. Effect of biologically synthesized silver nanoparticles on Bacopa monnieri (Linn.) Wettst. plant growth metabolism. Process Biochem 47, 651-658 (2012).

57. $\mathrm{Zu}$, Y. et al. Effects of arsenic treatments on saponin content and heterogeneity extracted from rhizome and main root of Panax notoginseng plants grown in shaded field. J. Geosci. Environ Prot 4, 15 (2016).

58. Ghanati, F. \& Bakhtiarian, S. Effect of methyl jasmonate and silver nanoparticles on production of secondary metabolites by Calendula officinalis L (Asteraceae). Trop. J. Pharmaceut. Res 13, 1783-1789 (2014).

59. Khan, M. S., Zaka, M., Abbasi, B. H. \& Shah, A. Seed germination and biochemical profile of Silybum marianum exposed to monometallic and bimetallic alloy nanoparticles. IET Nanobiotechnol (2016).

60. Javed, R., Usman, M., Yücesan, B., Zia, M. \& Gürel, E. Effect of zinc oxide (ZnO) nanoparticles on physiology and steviol glycosides production in micropropagated shoots of Stevia rebaudiana Bertoni. Plant Physiol. Biochem (2016).

61. Hinneburg, I., Dorman, H. D. \& Hiltunen, R. Antioxidant activities of extracts from selected culinary herbs and spices. Food Chem 97, 122-129(2006).

62. Amarowicz, R., Pegg, R., Rahimi-Moghaddam, P., Barl, B. \& Weil, J. Free-radical scavenging capacity and antioxidant activity of selected plant species from the Canadian prairies. Food Chem 84, 551-562 (2004).

63. Sergiev, I., Alexieva, V. \& Karanov, E. Effect of spermine, atrazine and combination between them on some endogenous protective systems and stress markers in plants. Compt. Rend. Acad. Bulg. Sci. 51, 121-124 (1997).

64. Aebi, H. Catalase in vitro. Meth.Enzymol 105, 121-126 (1984).

65. Nakano, Y. \& Asada, K. Hydrogen peroxide is scavenged by ascorbate-specific peroxidase in spinach chloroplasts. Plant. Cell. Physiol. 22, 867-880 (1981)

66. Chance, B. \& Maehly, A. Assay of catalases and peroxidases. Met. Enzymol. 2, 764-775 (1955).

67. Giannopolitis, C. N. \& Ries, S. K. Superoxide dismutases I. Occurrence in higher plants. Plant physiol. 59, 309-314 (1977).

68. Singleton, V. L., Orthofer, R. \& Lamuela-Raventos, R. M. Analysis of total phenols and other oxidation substrates and antioxidants by means of folin-ciocalteu reagent. Method. Enzymol 299, 152-178 (1999).

69. Hiai, S., Oura, H. \& Nakajima, T. Color reaction of some sapogenin and saponins with vanilin and sulfuric acid. Planta Med. 29, 116-122 (1976).

70. Haag-Berrurier, M., Kuballa, B. \& Anton, R. Dosage des glucoiridoïdes totaux dans la racine d'Harpagophytum procumbens. DC. Plant. Med. Phytotherap. 12, 197-206 (1978).

71. Prieto, P., Pineda, M. \& Aguilar, M. Spectrophotometric quantitation of antioxidant capacity through the formation of a phosphomolybdenum complex: specific application to the determination of vitamin E. Anal.Biochem. 269, 337-341 (1999).

72. Sarker, S.D., Latif, Z. \& Gray, A. I. (Eds.). Natural Products Isolation, 20 (Humana Press Inc., NJ, USA, 2006).

73. Aman, S. et al. Antioxidant activity of thymol: protective role in AAPH-induced hemolysis in diabetic erythrocytes. IJPSI. 2, 55-60 (2013). 


\section{Acknowledgements}

We would like to thanks the graduate school of Razi University for providing research facilities for this study.

\section{Author contributions}

A.C., designed the work and performed the experiments. F.Q., analyzed the data statically. N.K., guided the project design. The manuscript was written by A.C., and X.M., edited the text. All authors reviewed the manuscript.

\section{Competing interests}

The authors declare no competing interests.

\section{Additional information}

Correspondence and requests for materials should be addressed to A.C.

Reprints and permissions information is available at www.nature.com/reprints.

Publisher's note Springer Nature remains neutral with regard to jurisdictional claims in published maps and institutional affiliations.

(c) (i) Open Access This article is licensed under a Creative Commons Attribution 4.0 International License, which permits use, sharing, adaptation, distribution and reproduction in any medium or format, as long as you give appropriate credit to the original author(s) and the source, provide a link to the Creative Commons license, and indicate if changes were made. The images or other third party material in this article are included in the article's Creative Commons license, unless indicated otherwise in a credit line to the material. If material is not included in the article's Creative Commons license and your intended use is not permitted by statutory regulation or exceeds the permitted use, you will need to obtain permission directly from the copyright holder. To view a copy of this license, visit http://creativecommons.org/licenses/by/4.0/.

(C) The Author(s) 2020 